\title{
The association between palatal rugae pattern and dental malocclusion
}

Farheen Fatima ${ }^{1}$, Mubassar Fida$^{1}$, Attiya Shaikh²

DOI: https://doi.org/10.1590/2177-6709.24.1.37.e1-9.onl

Introduction: Palatal rugae complete its development during early intrauterine life, whereas dental malocclusions in permanent dentition establishes several years into the post-natal life. Objective: The objective of present study was to determine if there is an association between the palatal rugae pattern and Angle's classes of malocclusion. Methods: A cross-sectional study was conducted on pretreatment dental casts of 184 patients. The sample was divided into the following groups: Class I, Class II div. 1, Class II div. 2, and Class III. The number of palatal rugae was recorded, bilaterally. The length, pattern and orientation of three anterior-most primary rugae on both sides were recorded. Results: The mean age of the study sample was $17.8 \pm 5.4$ years. The mean number of the palatal rugae was $11.18 \pm 2.5$, with significant differences among different malocclusion groups. The length of the first rugae on left side and third rugae on both sides varied significantly among the groups $(p<0.05)$. Similarly, the pattern of palatal rugae was also found to be significantly different among the malocclusion groups. The right sided rugae did not have any significant difference in the orientation in different malocclusion groups; however, the left sided rugae showed significant differences among the four malocclusion groups $(p<0.001)$. Conclusions: The current study showed subtle differences in the palatal rugae pattern among the Angle's classes of malocclusion. Similarly, the length and orientation of some rugae were also found to be significantly different between malocclusion groups.

Keywords: Palate. Malocclusion. Dental models.

Introdução: as rugas palatinas completam seu desenvolvimento ainda no início da vida intrauterina, enquanto as más oclusões dentárias na dentição permanente se estabelecem após vários anos de vida pós-natal. Objetivos: o presente estudo foi planejado para determinar se há associação entre o padrão das rugas palatinas e as más oclusões, segundo a classificação Angle. Métodos: um estudo transversal foi conduzido a partir dos modelos dentários pré-tratamento de 184 pacientes. A amostra foi dividida em quatro grupos: Classe I; Classe II, divisão 1; Classe II, divisão 2 e Classe III. O número de rugas palatinas foi registrado bilateralmente. O comprimento, padrão e a orientação das três rugas primárias mais anteriores de ambos os lados foram registrados. Resultados: a idade média da amostra desse estudo foi de 17,8 $\pm 5,4$ anos. O número médio de rugas palatinas foi de 11,18 $\pm 2,5$, com diferenças significativas entre os grupos de más oclusões. O comprimento da primeira ruga do lado esquerdo e da terceira ruga em ambos os lados variou significativamente entre os grupos $(p<0,05)$. De forma semelhante, o padrão das rugas palatinas também mostrou diferença significativa entre os grupos com diferentes má oclusões. As rugas do lado direito não apresentaram nenhuma diferença significativa de orientação nos diferentes grupos; no entanto, as rugas do lado esquerdo apresentaram diferenças significativas nos grupos estudados $(p<0,001)$. Conclusões: o presente estudo demonstrou diferenças sutis quanto ao padrão das rugas palatinas entre as classes de má oclusão definidas por Angle. Do mesmo modo, o comprimento e a orientação de algumas rugas também se apresentaram consideravelmente diferentes entre os grupos com diferentes má oclusões.

Palavras-chave: Palato. Má oclusão. Modelos dentários.

${ }^{1}$ The Aga Khan University Hospital, Section of Dentistry, Department of Surgery (Karachi, Pakistan).

${ }^{2}$ Liaquat College of Medicine and Dentistry, Department of Orthodontics (Karachi, Pakistan).

» The authors report no commercial, proprietary or financial interest in the products or companies described in this article.
How to cite: Fatima F, Fida M, Shaikh A. The association between palatal rugae pattern and dental malocclusion. Dental Press J Orthod. 2019 Jan-Feb;24(1):37.e1-9. DOI: https://doi.org/10.1590/2177-6709.24.1.37.e1-9.onl

Submitted: January 08, 2018 - Revised and accepted: March 03, 2018

Contact address: Farheen Fatima

E-mail: farheen_fatimas@homail.com. 


\section{INTRODUCTION}

The palatal rugae are unique structures that are inalterable in their position and pattern throughout the life of an individual. This imparts them a special role in the forensic Dentistry, having potential implications in the process of human identification. ${ }^{1-3}$ In Orthodontics, they are used as stable reference landmarks for the superimposition of pre- and post-treatment cephalometric tracings. ${ }^{4}$ Palatal rugae appear during the third month of intrauterine life and occupy most of the length of palatal shelves. These structures form a series of anatomical folds on the anterior part of the palatal mucosa, behind the incisive papilla on each side of the median palatal raphe. ${ }^{5}$ The number varies from 4 to 6 on each side, and they appear before the fusion of the palatine shelves. Their growth and development is controlled by the interaction between epithelial and mesenchymal cells. By the end of intrauterine life, the pattern becomes irregular, the posterior ones disappear and the anterior ones increases in prominence. ${ }^{6-8}$ They are protected by the surrounding soft and hard tissues - i.e., lips, cheeks, tongue, teeth and bone - , which guards them against trauma and high temperature. Their role has been established in deglutition and oral sensation; however, their precise role in sensorineural function is not entirely understood. ${ }^{9,10}$

The craniofacial growth and development occur via complex interaction between fibroblast growth factors and Hedgehog signaling pathways. ${ }^{11-13}$ Some studies have reported strong contribution of genetic factors to the malocclusion susceptibility. ${ }^{14,15}$ Polygenic inheritance has been reported for Class II subdivision 1; while Class II subdivision 2 and Class III malocclusion showed autosomal dominant inheritance. ${ }^{16-18}$ In the recent years, several papers have been published exploring the genetic pathways and molecular basis during the formation of palatal rugae. $3,11,13,19$

Malocclusion causes aesthetic concerns and functional impairment that may result in long term impact on the psychological health. An emphasis has been placed on the early diagnosis, as this may provide an advantage of preventive or interceptive treatment that may reduce disease burden and treatment duration. ${ }^{20}$ Since, the palatal rugae are stable structures and follow common signaling pathway during craniofacial development, its association with Angle's classes of malocclusion can be helpful for the predic- tion of forthcoming dentoskeletal aberrations. A survey of pertinent literature showed that, apart from a pilot study, no data has been available describing association of palatal rugae with various malocclusions traits. ${ }^{15}$ Therefore, the purpose of the present study was to investigate whether an association exists between morphological features of palatal rugae and Angle's classes of malocclusion.

\section{MATERIAL AND METHODS}

A retrospective cross-sectional study was conducted on the pre-treatment dental casts of $184 \mathrm{pa-}$ tients (92 males, 92 females) presenting to treatment in the last five years. Pretreatment dental records of 5,000 subjects were evaluated, and subjects who matched the inclusion criteria were selected. Ethical clearance was obtained from the ethical review committee (reference \#4075-16) prior to data collection. The sample size was calculated using the findings of Gandikota et al, ${ }^{21}$ who reported mean length of primary palatal rugae as $20.54 \pm 2.46 \mathrm{~mm}$ and $19.11 \pm 1.78 \mathrm{~mm}$ in Angle's Class I and Class II, respectively. The power was set at $80 \%$ and alpha was kept as 0.05 .

\section{Subjects and study groups}

The sample was divided into four equal groups, with 46 subjects in each group. The subjects were categorized on the basis of molar and incisor relationships (i.e. Class I, Class II division 1, Class II division 2 and Class III), and full unit cases were considered respective to incisor relations. Each malocclusion group had equal number of male and female subjects.

The sample was obtained from Pakistani population as confirmed by National identity card. Only subjects with good-quality dental casts were included in the study. All subjects were in the age range of 12-30 years, with full permanent dentition, well-established molar and incisor relationships and normal vertical growth pattern. Subjects with quarter or half-cusp molar relation, subdivision and asymmetric cases, and complex cases with unmatched molar and incisor relations were excluded. Moreover, patients with history of extraction or previous orthodontic treatment, cleft lip and palate, craniofacial and dental anomalies, 
pathology or trauma involving the head and neck region, habits such as tongue thrusting or thumb sucking and carious or missing molars and incisors were also excluded from the study.

\section{Dental cast analysis}

Study was conducted on the high-quality pretreatment dental stone models (white orthodontic stone, ISO type 3) derived from the alginate impressions of upper and lower dental arches. The palatal rugae were outlined with a sharp HB pencil under suitable light, and magnification. The most medial and distal ends of the palatal rugae were marked on dental cast and linear distances were measured using digital vernier calipers (0-150 mm ME00183, Dentaurum, Pforzheim, Germany) (Fig 1).

\section{Assessment of features of palatal rugae}

Based on length, the rugae were categorized as primary $(>5 \mathrm{~mm})$, secondary $(3-5 \mathrm{~mm})$, and fragmentary type $(<3 \mathrm{~mm}) .{ }^{8}$ The total number of rugae was recorded for both right and left sides. The three anterior-most primary rugae (labelled as ruga 1, 2 and 3) were observed for the length, pattern and orientation. For the assessment of pattern and orientation, the rugae were classified according to the method described by Hauser et al ${ }^{5}$ (Figs 2 and 3).

\section{STATISTICAL ANALYSIS}

Data were analyzed using SPSS for Windows (version 20.0, SPSS Inc. Chicago). The Shapiro-Wilk test was applied to test the normality of data, which showed a non-normal distribution; hence non-parametric test was applied. The Mann-Whitney $U$ test was applied to compare the study parameters between genders. Descriptive statistics for the palatal rugae lengths, i.e. means and standard deviations (SD), were calculated. The Kruskal-Wallis test was used to compare the mean differences in the palatal rugae number and length among the four malocclusion groups. The pattern and orientation were compared across the four groups using the Chi-square test. To rule out any error in measurement, 30 dental casts were reevaluated by the main investigator using intraclass correlation coefficient for quantitative variables and Kappa statistics for the qualitative variables. A p-value $\leq 0.05$ was considered as statistically significant.

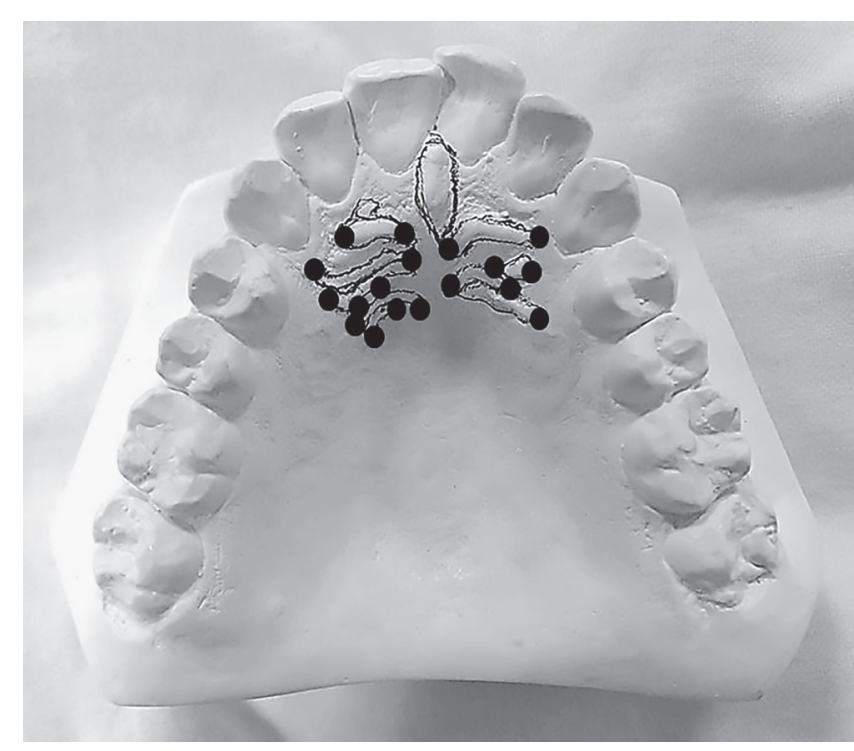

Figure 1 - Palatal rugae tracing on dental cast.

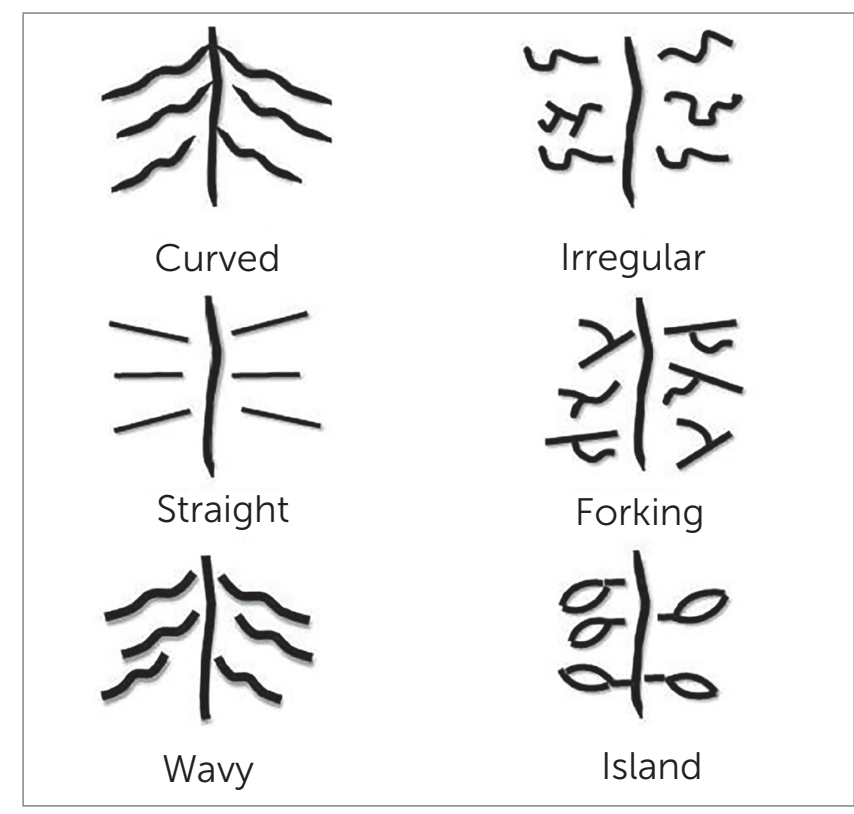

Figure 2 - Patterns of palatal rugae.

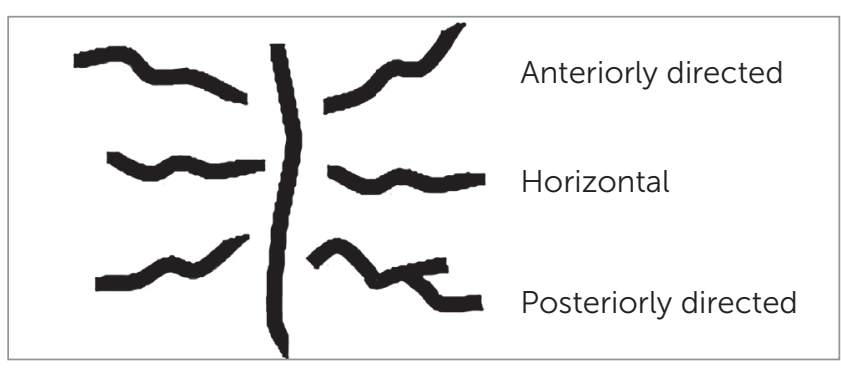

Figure 3 - Orientation of palatal rugae. 


\section{RESULTS}

The measurement error was evaluated and the results showed fair to excellent agreement between the two sets of reading in the assessment of rugae number and length, whereas pattern and orientation assessment showed moderate to excellent agreement (Tables 1 and 2). The comparison between sexes, regarding number of palatal rugae, and length, pattern and orientation of primary rugae, showed insignificant differences; therefore, further statistical analyses were not performed separately.

Statistically significant differences were found in the number of rugae among malocclusion groups (Table 3 ). The mean lengths of the primary rugae are shown in Table 4 . There were significant differ-

Table 1 - Assessment of the reliability of measurements.

\begin{tabular}{|c|c|c|c|c|c|}
\hline & \multirow[b]{2}{*}{ Palatal rugae } & & \multicolumn{2}{|c|}{ Mean \pm SD } & \multirow[b]{2}{*}{ ICC } \\
\hline & & & $\begin{array}{l}\text { First reading } \\
\qquad(\mathrm{n}=30)\end{array}$ & $\begin{array}{l}\text { Second reading } \\
\qquad(n=30)\end{array}$ & \\
\hline \multirow{6}{*}{ Number of rugae } & \multirow{2}{*}{ Primary } & Right & $4.27 \pm 9.8$ & $4.13 \pm 1.1$ & 0.9 \\
\hline & & Left & $4.50 \pm 1.1$ & $4.63 \pm 1.2$ & 0.8 \\
\hline & \multirow{2}{*}{ Secondary } & Right & $1.27 \pm 9.4$ & $1.60 \pm 1.0$ & 0.8 \\
\hline & & Left & $1.13 \pm 1.0$ & $1.33 \pm 0.9$ & 0.8 \\
\hline & \multirow{2}{*}{ Fragmentary } & Right & $0.43 \pm 0.6$ & $0.93 \pm 0.8$ & 0.7 \\
\hline & & Left & $0.40 \pm 0.6$ & $0.80 \pm 0.7$ & 0.7 \\
\hline \multirow{6}{*}{$\begin{array}{l}\text { Length of primary rugae } \\
\qquad(\mathrm{mm})\end{array}$} & \multirow{2}{*}{ First } & Right & $8.51 \pm 1.2$ & $8.69 \pm 1.4$ & 0.9 \\
\hline & & Left & $8.19 \pm 2.0$ & $8.58 \pm 2.0$ & 0.9 \\
\hline & \multirow{2}{*}{ Second } & Right & $8.44 \pm 2.0$ & $8.77 \pm 2.0$ & 0.9 \\
\hline & & Left & $8.82 \pm 1.9$ & $8.99 \pm 2.3$ & 0.9 \\
\hline & \multirow{2}{*}{ Third } & Right & $10.14 \pm 2.5$ & $10.06 \pm 2.5$ & 0.9 \\
\hline & & Left & $9.17 \pm 2.5$ & $9.31 \pm 2.4$ & 0.9 \\
\hline
\end{tabular}

$\mathrm{n}=30 ; \mathrm{SD}=$ standard deviation; > $0.75=$ excellent agreement; $0.4-0.75$ = fair agreement; $<0.4=$ poor agreement.

$\mathrm{ICC}=$ Intraclass correlation coefficient

Table 2 - Assessment of the reliability of measurements.

\begin{tabular}{|c|c|c|c|c|}
\hline & Palatal rugae & & к & p-value \\
\hline \multirow{6}{*}{ Pattern of primary rugae } & \multirow{2}{*}{ First } & Right & 0.6 & 0.00 \\
\hline & & Left & 0.8 & 0.00 \\
\hline & \multirow{2}{*}{ Second } & Right & 0.6 & 0.00 \\
\hline & & Left & 0.8 & 0.00 \\
\hline & \multirow{2}{*}{ Third } & Right & 0.6 & 0.00 \\
\hline & & Left & 0.6 & 0.00 \\
\hline \multirow{6}{*}{ Orientation of primary rugae } & \multirow{2}{*}{ First } & Right & 0.6 & 0.00 \\
\hline & & Left & 0.6 & 0.00 \\
\hline & \multirow{2}{*}{ Second } & Right & 0.7 & 0.00 \\
\hline & & Left & 0.8 & 0.00 \\
\hline & \multirow{2}{*}{ Third } & Right & 0.9 & 0.00 \\
\hline & & Left & 0.8 & 0.00 \\
\hline
\end{tabular}

$n=30 ; S D=$ standard deviation; $\kappa=$ Cohen's kappa; $\leq 0=$ no agreement; $0.01-0.20=$ none to slight; $0.21-0.40=$ fair $; 0.41-0.60=$ moderate; $0.61-0.80=$ substantial; 0.81-1.00 = perfect agreement. 
ences in mean lengths among the groups in ruga 1 on left side $(p<0.001)$ and rugae 3 on both right $(p=0.03)$ and left $(p<0.001)$ sides. Curved pattern was predominant and significant differences were found among the groups $(p<0.05)$; however, the results did not show any specific pattern peculiar to any malocclusion type. The distribution of differ- ent rugae pattern is shown in Table 5 . There was no significant differences for the orientation among the groups on right side; however, left side showed significant differences for the ruga $1(p=0.001)$, ruga 2 $(p=0.004)$ and ruga $3(p=0.013)$. The distribution of orientation of the rugae among the malocclusion groups is shown in Table 6 .

Table 3 - Mean number of palatal rugae among malocclusion groups.

\begin{tabular}{|c|c|c|c|c|c|c|}
\hline \multirow{2}{*}{\multicolumn{2}{|c|}{ Number of rugae }} & \multicolumn{4}{|c|}{ Molar Class } & \multirow{2}{*}{ p-value } \\
\hline & & Class I & Class II/1 & Class II/2 & Class III & \\
\hline \multirow{2}{*}{ Primary } & Right & $4.33 \pm 1.0$ & $3.87 \pm 1.0$ & $3.87 \pm 0.8$ & $4.02 \pm 0.7$ & $0.05^{\star}$ \\
\hline & Left & $4.37 \pm 1.0$ & $3.70 \pm 0.6$ & $4.04 \pm 0.8$ & $4.07 \pm 0.8$ & $<0.001^{* *}$ \\
\hline \multirow{2}{*}{ Secondary } & Right & $1.07 \pm 0.9$ & $1.26 \pm 0.8$ & $0.70 \pm 0.8$ & $1.00 \pm 0.8$ & $<0.001^{\star *}$ \\
\hline & Left & $1.22 \pm 0.9$ & $1.24 \pm 0.7$ & $0.83 \pm 0.8$ & $0.89 \pm 0.8$ & $0.02^{*}$ \\
\hline \multirow{2}{*}{ Fragmentary } & Right & $0.28 \pm 0.5$ & $0.41 \pm 0.7$ & $0.54 \pm 0.9$ & $0.67 \pm 0.7$ & $0.01^{\star}$ \\
\hline & Left & $0.35 \pm 0.6$ & $0.59 \pm 0.6$ & $0.76 \pm 0.7$ & $0.67 \pm 0.8$ & $0.02^{*}$ \\
\hline
\end{tabular}

$n=184 ;$ Kruskal-Wallis test, ${ }^{*} p<0.05 ;{ }^{* *} p<0.001$.

Table 4 - Mean lengths of palatal rugae among malocclusion groups.

\begin{tabular}{|c|c|c|c|c|c|c|}
\hline \multirow{2}{*}{\multicolumn{2}{|c|}{ Length of primary rugae ( $\mathrm{mm}$ ) }} & \multicolumn{4}{|c|}{ Molar Class } & \multirow{2}{*}{ p-value } \\
\hline & & Class I & Class II/1 & Class II/2 & Class III & \\
\hline \multirow{2}{*}{ First } & Right & $8.64 \pm 1.3$ & $8.27 \pm 1.5$ & $8.16 \pm 1.2$ & $8.56 \pm 1.2$ & 0.36 \\
\hline & Left & $8.34 \pm 1.9$ & $9.60 \pm 2.0$ & $9.62 \pm 1.1$ & $9.01 \pm 1.2$ & $<0.001^{\star *}$ \\
\hline \multirow{2}{*}{ Second } & Right & $8.95 \pm 2.5$ & $9.22 \pm 2.1$ & $9.25 \pm 2.1$ & $9.71 \pm 2.4$ & 0.52 \\
\hline & Left & $8.59 \pm 1.8$ & $8.66 \pm 1.7$ & $8.94 \pm 2.2$ & $9.69 \pm 2.4$ & 0.09 \\
\hline \multirow{2}{*}{ Third } & Right & $9.70 \pm 2.5$ & $10.31 \pm 3.1$ & $11.03 \pm 2.6$ & $10.87 \pm 2.4$ & $0.03^{*}$ \\
\hline & Left & $9.38 \pm 2.1$ & $10.88 \pm 2.5$ & $10.60 \pm 1.8$ & $11.94 \pm 2.3$ & $<0.001^{*}$ \\
\hline
\end{tabular}

$n=184 ;$ Kruskal-Wallis test, ${ }^{*} p<0.05 ;{ }^{* *} p<0.001$. 
Table 5 - Comparison of pattern of primary palatal rugae among malocclusion groups.

\begin{tabular}{|c|c|c|c|c|c|c|c|}
\hline \multirow{2}{*}{\multicolumn{3}{|c|}{ Patterns of primary rugae }} & \multicolumn{4}{|c|}{ Molar Class } & \multirow{2}{*}{ p-value } \\
\hline & & & Class I & Class II/1 & Class II/2 & Class III & \\
\hline \multirow{12}{*}{ First } & \multirow{6}{*}{ Right } & Curved & 24 & 26 & 25 & 22 & \multirow{6}{*}{$0.008^{*}$} \\
\hline & & Straight & 14 & 6 & 5 & 12 & \\
\hline & & Wavy & 1 & 0 & 0 & 0 & \\
\hline & & Irregular & 0 & 0 & 0 & 0 & \\
\hline & & Forking & 7 & 14 & 16 & 8 & \\
\hline & & Island & 0 & 0 & 0 & 4 & \\
\hline & \multirow{6}{*}{ Left } & Curved & 26 & 26 & 22 & 14 & \multirow{6}{*}{$0.007^{*}$} \\
\hline & & Straight & 11 & 5 & 5 & 12 & \\
\hline & & Wavy & 0 & 0 & 0 & 0 & \\
\hline & & Irregular & 0 & 0 & 0 & 0 & \\
\hline & & Forking & 8 & 15 & 19 & 16 & \\
\hline & & Island & 1 & 0 & 0 & 4 & \\
\hline \multirow{12}{*}{ Second } & \multirow{6}{*}{ Right } & Curved & 42 & 20 & 24 & 21 & \multirow{6}{*}{$<0.001^{* *}$} \\
\hline & & Straight & 4 & 8 & 8 & 6 & \\
\hline & & Wavy & 0 & 2 & 7 & 6 & \\
\hline & & Irregular & 0 & 0 & 0 & 0 & \\
\hline & & Forking & 0 & 16 & 7 & 13 & \\
\hline & & Island & 0 & 0 & 0 & 0 & \\
\hline & \multirow{6}{*}{ Left } & Curved & 28 & 21 & 34 & 30 & \multirow{6}{*}{$0.001^{\star *}$} \\
\hline & & Straight & 10 & 7 & 4 & 6 & \\
\hline & & Wavy & 8 & 4 & 4 & 6 & \\
\hline & & Irregular & 0 & 0 & 0 & 0 & \\
\hline & & Forking & 0 & 14 & 4 & 4 & \\
\hline & & Island & 0 & 0 & 0 & 0 & \\
\hline \multirow{12}{*}{ Third } & \multirow{6}{*}{ Right } & Curved & 33 & 34 & 36 & 28 & \multirow{6}{*}{$0.003^{*}$} \\
\hline & & Straight & 8 & 3 & 0 & 4 & \\
\hline & & Wavy & 5 & 2 & 5 & 2 & \\
\hline & & Irregular & 0 & 0 & 0 & 0 & \\
\hline & & Forking & 0 & 7 & 5 & 12 & \\
\hline & & Island & 0 & 0 & 0 & 0 & \\
\hline & \multirow{6}{*}{ Left } & Curved & 25 & 38 & 36 & 32 & \multirow{6}{*}{$0.01^{*}$} \\
\hline & & Straight & 8 & 1 & 5 & 6 & \\
\hline & & Wavy & 12 & 2 & 5 & 6 & \\
\hline & & Irregular & 0 & 0 & 0 & 0 & \\
\hline & & Forking & 1 & 4 & 0 & 2 & \\
\hline & & Island & 0 & 0 & 0 & 0 & \\
\hline
\end{tabular}

$n=184$; Chi-square test, ${ }^{\star} p<0.05 ;{ }^{* *} p<0.001$. 
Table 6 - Comparison of orientation of primary palatal rugae among malocclusion groups.

\begin{tabular}{|c|c|c|c|c|c|c|c|}
\hline \multirow{2}{*}{\multicolumn{3}{|c|}{ Orientation of primary rugae }} & \multicolumn{4}{|c|}{ Molar Class } & \multirow{2}{*}{ p-value } \\
\hline & & & Class I & Class II/1 & Class II/2 & Class III & \\
\hline \multirow{6}{*}{ First } & \multirow{3}{*}{ Right } & $\begin{array}{c}\text { Posteriorly } \\
\text { directed }\end{array}$ & 26 & 25 & 37 & 31 & \multirow{3}{*}{0.13} \\
\hline & & Horizontal & 7 & 9 & 5 & 5 & \\
\hline & & $\begin{array}{c}\text { Anteriorly } \\
\text { directed }\end{array}$ & 13 & 12 & 4 & 10 & \\
\hline & \multirow{3}{*}{ Left } & $\begin{array}{c}\text { Posteriorly } \\
\text { directed }\end{array}$ & 24 & 29 & 41 & 37 & \multirow{3}{*}{$0.001^{\star *}$} \\
\hline & & Horizontal & 14 & 7 & 2 & 6 & \\
\hline & & $\begin{array}{c}\text { Anteriorly } \\
\text { directed }\end{array}$ & 8 & 10 & 3 & 3 & \\
\hline \multirow{6}{*}{ Second } & \multirow{3}{*}{ Right } & $\begin{array}{c}\text { Posteriorly } \\
\text { directed }\end{array}$ & 7 & 17 & 15 & 16 & \multirow{3}{*}{0.11} \\
\hline & & Horizontal & 9 & 5 & 7 & 2 & \\
\hline & & $\begin{array}{c}\text { Anteriorly } \\
\text { directed }\end{array}$ & 30 & 24 & 24 & 28 & \\
\hline & \multirow{3}{*}{ Left } & $\begin{array}{c}\text { Posteriorly } \\
\text { directed }\end{array}$ & 20 & 18 & 32 & 31 & \multirow{3}{*}{$0.004^{*}$} \\
\hline & & Horizontal & 10 & 5 & 6 & 6 & \\
\hline & & $\begin{array}{c}\text { Anteriorly } \\
\text { directed }\end{array}$ & 16 & 23 & 8 & 9 & \\
\hline \multirow{6}{*}{ Third } & \multirow{3}{*}{ Right } & $\begin{array}{c}\text { Posteriorly } \\
\text { directed }\end{array}$ & 9 & 14 & 20 & 10 & \multirow{3}{*}{0.15} \\
\hline & & Horizontal & 2 & 1 & 0 & 2 & \\
\hline & & $\begin{array}{c}\text { Anteriorly } \\
\text { directed }\end{array}$ & 35 & 31 & 26 & 34 & \\
\hline & \multirow{3}{*}{ Left } & $\begin{array}{c}\text { Posteriorly } \\
\text { directed }\end{array}$ & 14 & 18 & 25 & 29 & \multirow{3}{*}{$0.013^{*}$} \\
\hline & & Horizontal & 8 & 3 & 7 & 3 & \\
\hline & & $\begin{array}{c}\text { Anteriorly } \\
\text { directed }\end{array}$ & 24 & 25 & 14 & 14 & \\
\hline
\end{tabular}

$n=184 ;$ Chi-square test, ${ }^{*} p<0.05 ;{ }^{* *} p<0.001$

\section{DISCUSSION}

The characteristics of palatal rugae are unique to an individual. Variations may be seen among both sexes; however, the literature review shows conflicting evidence in various populations. Some studies have stated insignificant sexual dimorphism in rugae pattern; whereas other studies have reported significant differences among male, female, and transgender populations.,22-25 However, in the present study, it was found no significant differences between male and female groups regarding the number of palatal rugae, and length, pattern and orientation of primary palatal rugae. The differences in results could be due to ethnic variation. In the current study, the average number of primary rugae was close to three, which is in concordance with the results of previous studies. ${ }^{6,26}$ The mean number of palatal rugae was observed to be greatest in Class I subjects, and the mean lengths of primary rugae were found to be comparable among the four malocclusion groups. In contrast, Kapoor et $\mathrm{al}^{6}$ reported the highest number of palatal rugae in Class II division 2 group and shorter length of first, second and third rugae in Class II division 1, as compared to Class I group, in an Indian population. However they conducted a pilot study and the subjects were not evenly distributed in the malocclusion groups, whereas the present study was conducted on an adequate sample with comparable number of subjects in each group. 
The role of palatal rugae in mastication, deglutition and speech has been reported in literature. ${ }^{9,10}$ Lysell $^{8}$ reported that the dorsal surface of tongue is an important determinant of rugae pattern. Tongue position may vary with type of malocclusion ${ }^{27}$; therefore, the pattern of rugae is expected to vary in different malocclusion classes. In Class II malocclusion, the tip of tongue is positioned more posteriorly, and dorsal portion is postured more superiorly, as compared to skeletal Class I malocclusion. ${ }^{28}$ Moreover, the tongue posture in posterior regions was found to be significantly lower in subjects with Class III malocclusion, as compared to Class I subjects. ${ }^{27}$ The present results showed significant differences in pattern of primary rugae among the study groups. Contrasting results were reported by Kapoor el al, ${ }^{6}$ which could be due to the small sample size in their study, which failed to detect the differences.

Strong genetic predisposition has been reported in the number, shape and orientation of palatal rugae. ${ }^{29,30}$ Orientation of the primary palatal rugae was found to have significant differences on the left side, and the first primary rugae were found to be posteriorly directed more frequently in Class II division 2 group. Previous study reported insignificant differences in the orientation of primary palatal rugae. ${ }^{7}$ The possible reason of conflicting results could be due to the fact that rugae are asymmetric structures and the mechanism of their development and establishment has been poorly understood. ${ }^{31}$ These results suggest that the developments of different structures in orofacial complex are related to each other, and may be subjected to similar epigenetic variations that may influence their phenotype. Further exploration of genetic variations at the molecular level can prove to be the gold standard to establish this relationship.

Different methods for the evaluation of palatal rugae on dental cast have been described in the literature. Optocom software, ${ }^{32}$ Reflex metrograph, ${ }^{33,34}$ photographs ${ }^{5}$ and photocopies of dental cast have been used in the past for the evaluation of palatal rugae. ${ }^{35}$ Each of these methods requires a sophisticated instrument, device or software that is not acquired by many investigators and clinicians. Kapali et $\mathrm{al}^{29}$ and Moran et $\mathrm{al}^{36}$ used slide vernier caliper to measure palatal landmarks. Digital vernier caliper was used in the current investigation as it is user-friendly and can be used directly on dental cast; therefore, does not require cast digitization and particular expertise.

Limitations of the present study were manual tracing of palatal rugae for the assessment of morphological characteristics, and a single investigator assessing the dental casts. Moreover, assessment of pattern and orientation of rugae is subjective. With recent technological advancement, study casts can be scanned with a three-dimensional scanner and measurements can be done in three dimensions on computer screen, for more reliable results.

\section{CONCLUSIONS}

The current study found an association between the number of palatal rugae and the pattern of primary rugae with the Angle's classes of malocclusion. However, the length and the orientation of the primary palatal rugae showed variable results.

\section{Author's contribution (ORCID ${ }^{(0)}$ )}

Farheen Fatima (FF): 0000-0001-5945-7185

Mubassar Fida (MF): 0000-0003-4842-9896 ${ }^{\circ}$

Attiya Shaikh (AS): 0000-0002-3553-0365 ${ }^{\circ}$

Conception or design of the study: FF, MF, AS. Data acquisition, analysis or interpretation: FF, MF, AS. Writing the article: FF, MF, AS. Critical revision of the article: FF, MF, AS. Final approval of the article: FF, MF, AS. Obtained funding: FF, MF, AS. Overall responsibility: FF, MF, AS. 


\section{REFERENCES}

1. English WR, Robison SF, Summitt JB, Oesterle LJ, Brannon RB Morlang WM. Individuality of human palatal rugae. J Forensic Sci. 1988 May:33(3):718-26.

2. Saraf A, Bedia S, Indurkar A, Degwekar S, Bhowate R. Rugae patterns as an adjunct to sex differentiation in forensic identification. J Forensic Odontostomatol. 2011 July 1:29(1):14-9

3. Vastardis $\mathrm{H}$, KarimbuxEconomou AD, Ohazama A, Sharpe PT, Kondo S, Basson MA, et al. Periodic stripe formation by a Turing mechanism operating at growth zones in the mammalian palate. Nat. Genet. 2012:44(3):348-51

4. Hoggan BR, Sadowsky C. The use of palatal rugae for the assessment of anteroposterior tooth movements. Am J Orthod Dentofacial Orthop. 2001 May:119(5):482-8

5. Hauser G, Daponte A, Roberts MJ. Palatal rugae. J Anat. 1989:165:237-49.

6. Kapoor P, Ragini, Kaur H. Rugoscopy: a diagnostic appurtenance for malocclusion or just a forensic aid? A pilot study. J Forensic Res. 2015:6:272.

7. Lee JM, Miyazawa S, Shin JO, Kwon HJ, Kang DW, Choi BJ, et al. Shh signaling is essential for rugae morphogenesis in mice. Histochem Cell Biol. 2011 Dec:136(6):663-75

8. Lysell L. Plicae palatinae transversae and papilla incisive in man: a morphologic and genetic study. Acta Odontol Scand. 1955;13(Suppl 18):5-137

9. Nunzi MG, Pisarek A, Mugnaini E. Merkel cells, corpuscular nerve endings and free nerve endings in the mouse palatine mucosa express three subtypes of vesicular glutamate transporters. J Neurocytol. 2004 May:33(3):359-76.

10. Patil MS, Patil SB, Acharya AB. Palatine rugae and their significance in clinical dentistry: a review of the literature. J Am Dent Assoc. 2008 Nov:139(11):1471-8

11. Cobourne MT, Sharpe PT. Making up the numbers: the molecular control of mammalian dental formula. Semin Cell Dev Biol. 2010 May:21(3):314-24.

12. Jang I, Tanaka M, Koga Y, lijima S, Yozgatian JH, Cha BK, et al. A novel method for the assessment of three-dimensional tooth movement during orthodontic treatment. Angle Orthod. 2009 May; 79(3):447-53.

13. Lin C, Fisher AV, Yin Y, Maruyama T, Veith GM, Dhandha M, et al. The inductive role of Wnt-b-Catenin signaling in the formation of oral apparatus. Dev Biol. 2011 Aug 1;356(1):40-50

14. Naini FB, Moss JP. Three-dimensional assessment of the relative contribution of genetics and environment to various facial parameters with the twin method. Am J Orthod Dentofacial Orthop. 2004 Dec;126(6):655-65

15. Townsend G, Hughes T, Luciano M, Bockmann M, Brook A. Genetic and environmental influences on human dental variation: a critical evaluation of studies involving twins. Arch Oral Biol. 2009 Dec;54 Suppl 1:S45-51

16. Harris JE. Genetic factors in the growth of the head. Inheritance of the craniofacial complex and malocclusion. Dent Clin North Am. 1975 Jan;19(1):151-60

17. Peck S, Peck L, Kataja M. Class II Division 2 malocclusion: a heritable pattern of small teeth in well-developed jaws. Angle Orthod. 1998 Feb;68(1):9-20

18. Xue F, Wong RWK, Rabie ABM. Genes, genetics, and Class III malocclusion. Orthod Craniofac Res. 2010 May;13(2):69-74.
19. Murdoch AM, Patir A, Seymen F, Vieira AR. Studies of palatine rugae and interferon regulatory factor 6 variations in a group of families with sporadic hypodontia. J Oral Sci. 2009 Dec;51(4):521-6.

20. Stenvik, A, Espeland L, Berg RE. A 57-year follow-up of occlusal changes, oral health, and attitudes toward teeth. Am J Orthod Dentofacial Orthop. 2011 Apr:139(4 Suppl):S102-8.

21. Gandikota C, Venkata YP, Challa P, Juvvadi SR, Mathur A. Comparative study of palatal rugae pattern in Class II div 1 and Class I individuals J Pharm Bioallied Sci. 2012 Aug:4(Suppl 2):S358-63

22. Gondivkar SM, Patel S, Gadbail AR, Gaikwad RN, Chole R, Parikh RV Morphological study of the palatal rugae in western Indian population. J Forensic Leg Med. 2011 Oct;18(7):310-2.

23. Jibi PM, Gautam KK, Basappa N, Raju OS. Morphological pattern of palatal rugae in children of Davangere. J Forensic Sci. 2011 Sept;56(5):1192-7.

24. Nayak P, Acharya AB, Padmini AT, Kaveri H. Differences in the palatal rugae shape in two populations of India. Arch Oral Biol. 2007 Oct:52(10):977-82. Epub 2007 May 31

25. Saxena E, Chandrashekhar BR, Hongal S, Torwane N, Goel P, Mishra P. A study of the palatal rugae pattern among male female and transgender population of Bhopal city. J Forensic Dent Sci. 2015 May-Aug:7(2):142-7.

26. Kallianpur S, Desai A, Kasetty S, Sudheendra U, Joshi P. An anthropometric analysis of facial height, arch length, and palatal rugae in the Indian and Nepalese population. J Forensic Dent Sci. 2011 JanJune; 3(1):33-7.

27. Primozic J, Farcnik F, Perinetti G, Richmond S, Ovsenik M. The association of tongue posture with the dentoalveolar maxillary and mandibular morphology in Class III malocclusion: a controlled study. Eur J Orthod. 2013 June:35(3):388-93.

28. Yilmaz F, Sagdiç D, Karaçay S, Akin E, Bulakbasi N. Tongue movements in patients with skeletal Class II malocclusion evaluated with real-time balanced turbo field echo cine magnetic resonance imaging. Am J Orthod Dentofacial Orthop. 2011 May; 139(5):e415-25

29. Kapali S, Townsend G, Richards L, Parish T. Palatal rugae patterns in Australian aborigines and Caucasians. Aust Dent J. 1997 Apr;42(2):129-33.

30. Nilles $K$. The palate relief as a diagnostic help in the anthropologic proof of paternity. Stoma (Heidelb). 1952 May; 5(2):121-5.

31. Blum M, Feistel K, Thumberger T, Schweickert A. The evolution and conservation of left-right patterning mechanisms. Development. 2014 Apr:141(8):1603-13.

32. Van der Linden FP. Changes in the position of posterior teeth in relation to ruga points. Am J Orthod. 1978 Aug:74(2):142-61.

33. Almeida MA, Phillips C, Kula K, Tulloch C. Stability of the palatal rugae as landmarks for analysis of dental casts. Angle Orthod. 1995;65(1):43-8

34. Bailey LT, Esmailnejad A, Almeida MA. Stability of the palatal rugae as landmarks for analysis of dental casts in extraction and nonextraction cases. Angle Orthod. 1996:66(1):73-8.

35. Rajcich MM, Sadowsky C. Efficacy of intraarch mechanics using differential moments for achieving anchorage control in extraction cases. Am J Orthod Dentofacial Orthop. 1997 Oct:112(4):441-8.

36. Moran A, Tippett H, Manoharan A, Cobourne MT. Alteration of palatine ruga pattern in subjects with oligodontia: A pilot study. Am J Orthod Dentofacial Orthop. 2016 Aug:150(2):295-302 